\title{
FRUIT RED COLORANTS IMPACT ON THE ANTIRADICAL ACTIVITY DETERMINED BY DPPH METHOD
}

\author{
Ondrej Hegedüs, Boglárka Borovicza, Katarína Szarka, Andrea Vargová, Dániel Reménység, \\ Adriána Mat'ová, Barnabás Czibor, Alžbeta Hegedüsová
}

\begin{abstract}
This work is focused on the determination of antiradical activity (ARA) by the method of free radical scavenging of 2,2Diphenyl-1-picrylhydrazyl (DPPH). Since the DPPH solution is intense purple-coloured and absorbs at a wavelength of $517 \mathrm{~nm}$, similar to the anthocyanin colorants of fruits, the modification of the method examined the effect of the colour of the sample extracts on the result of the ARA determination. Statistical evaluation of the results of the analyses using Youden's graphing method revealed that the two compared method adjustments gave consistent results over the observed range of antiradical activity. It also showed that there was no statistically significant difference between the mean ARA values obtained by the two treatments. Investigation of the effect of the evaluated fruit components revealed a strong correlation between the content of ascorbic acid and ARA in samples containing no anthocyanin colorants. For the fruit samples studied, ARA values showed a strong correlation with polyphenol content.
\end{abstract}

Keywords: DPPH method; antiradical activity; dependence; ascorbic acid; polyphenols

\section{INTRODUCTION}

The antioxidant capacity is often measured by a method based on decolorizing stable radicals of 2,2-Diphenyl-1picrylhydrazyl (DPPH) with various antioxidants. This method is simple, efficient, and relatively cheap. DPPH is commercially available, stable, and poorly sensitive to degradation, which will significantly affect its use. The DPPH colour is intense purple and shows a strong absorption band in the $515-520 \mathrm{~nm}$ range. The original method of DPPH analysis was developed by Marsen Blois (1958), which later underwent various modifications (Brand-Willams, Cuvelier, and Berset, 1995; Chen, Bertin, and Froldi, 2013) and are also widely used. The DPPH method is a mixed HAT (Hydrogen Atom Transfer) and SET (Single Electron Transfer) method, since, in the presence of an antioxidant molecule, DPPH can receive one electron or even one proton from the antioxidant molecule. This turns it into a more stable reduced form, which also changes its intense purple colour to faint yellow. The antiradical activity of the sample (ARA) can be quantified by spectrophotometric measurement of this conversion.

Measurement results are often expressed as "EC50 value", ("efficient concentration" or EC50 value), which represents the substrate concentration to achieve a $50 \%$ reduction in the original DPPH concentration. This parameter was introduced by Brand-Willams et al. (1995) and subsequently applied by a few adjustments to several groups of workers to present their results (Kedare and Singh, 2011). This parameter depends on the initial DPPH concentration as well as the chosen reaction time chosen by the authors over a relatively wide time span. This makes the comparability of the results more difficult but gives a good idea of the ARA value of the samples analysed.

Although considered to be simple and effective, this method is characterized by various limitations that make measurement difficult. Many studies have pointed out that there is no linear dependence between antioxidant concentration and DPPH radical scavenging activity. Thus, the EC50 expression can be problematic in many cases (Mishra, Ojha, and Chaudhury, 2012; CarmonaJiménez et al., 2014; Sánchez-Moreno, Larrauri and Saura-Calixto, 1998).

Some authors recommend measuring the result of a blank sample (Chang et al., 2001; Lachman et al., 2006; Jakobek et al., 2008; Vollmannová et al., 2013; Žiarovská et al., 2014), others recommend drawing the results to the absorbance value at time $\mathrm{T}_{0}$ for each sample separately (Dawidowicz, Wianowska, and Olszowy, 2012), whereby the possible interference of other colorants in the extract (e.g. carotenoids and anthocyanins) at the wavelength used of $517 \mathrm{~nm}$ would be eliminated (Apak et al., 2007).

The antioxidant activity itself is influenced by the presence of many compounds present in natural materials. 
First of all, it is a question of polyphenols and vitamin $\mathrm{C}$ (Jakobek and Seruga 2012; Hegedüs et al., 2015). The influence of content substances on antioxidant activity was also investigated by Ivanišová et al. (2010) and showed a very high correlation between DPPH content and polyphenol content and vitamin $\mathrm{C}$ content.

\section{Scientific hypothesis}

Based on the fact that samples of fruit extracts with a high content of anthocyanins strongly absorb wavelength light as well as DPPH solution, this may lead to differences in results when analysing intensively coloured extracts. The main objective of the work was based on the assumption that by modifying the method it is possible to correct this effect.

As the ARA value is influenced by different compounds, we assumed a dependence between the determined ARA value and some components by analysing a wide range of fruits.

\section{MATERIAL AND METHODOLOGY}

\section{Chemicals and Reagents}

2,2-Diphenyl-1-picrylhydrazyl (DPPH) and L-ascorbic acid CertiPUR were purchased from Merck, Darmstadt, Germany, Methanol from Fisher Scientific UK, Loughborough, UK, Gallic acid from MP Biomedicals, LLC, France and Folin-Ciocalteu reagent from VWR International S.A.S., France. All other reagents were of analytical reagent grade. Deionized water was used to prepare all solutions.

\section{Instrumentation}

Spectrophotometer Jenway 6301, Bibby Scientific Ltd., UK was used for absorption measurement. WATERS HPLC system with Waters 2489 UV/VIS Detector was used for ascorbic acid determination.

\section{Samples and Sample Preparation}

For the testing method purpose, we analysed 19 fruits from several growers from the districts of Komárno and Nové Zámky (elevation 110 - 150 m a.s.1.) from southern Slovakia. The assortment of fruits was supplemented with samples of southern fruits: bananas, lemons, and oranges, which were purchased from the retail network. These were the following fruit species: apricot (Prunus armeniaca L.), raspberry (Rubus idaeus L.), sour cherry (Prunus cerasus L.), blackcurrant (Ribes nigrum L.), redcurrant (Ribes rubrum L.), black mulberry (Morus nigra L.), josta (Ribes $\times$ nidigrolaria Rud. Bauer et A. Bauer), greengage yellow and red (Prunus domestica L. subsp. italica (Borkh.) Gams ex Hegi), gooseberry green (Ribes uva-crispa L.), gooseberry pink (Ribes uva-crispa L.), white mulberry (Morus alba L.), blueberry (Vaccinium myrtillus L.), cherry plum Nigra (Prunus cerasifera Ehrh. subsp. pissartii (Carriere) C. K. Scneid. cv. 'Nigra'), Sea buckthorn (Hippophae rhamnoides L.), common fig (Ficus carica L.), summer apple (Malus domestica Borkh.), white and red grapes (Vitis vinifera L.), banana (Musa $x$ paradisiaca L.), orange (Citrus sinensis (L.) Pers.), lemon (Citrus limon (L.) Burm.).

For the determination of ARA and polyphenols, methanol extracts were obtained from average samples of individual fruit species by extraction of $10 \mathrm{~g}$ of the sample in $70 \%$ methanol, which was used for spectrophotometric measurement.

\section{Methods of determination}

ARA was determined by DPPH and expressed as \% inhibition of DPPH radicals per $g$ of sample (Hegedüs et al., 2019a). Two modifications of the method were used:

- the absorbance results of the samples $30 \mathrm{~min}$ after the addition of DPPH were related to the initial absorbance of each sample separately,

- the absorbance results of the samples 30 min after the addition of DPPH were related to the absorbance of the blank.

The absorbance of the samples was measured at a wavelength of $517 \mathrm{~nm}$.

The anti-radical activity was calculated as the percentage of DPPH discoloration per $1 \mathrm{~g}$ sample using the following formula:

$$
\left.\% \operatorname{ARA}=\left(1-A \mathrm{t}_{30} / A \mathrm{t}_{0}\right) * 100 / n * V_{2} / V_{1}\right)
$$

Where: $\boldsymbol{A t}_{30}$ - absorbance of the sample after $30 \mathrm{~min}$; $\boldsymbol{n}$ - weigh of the sample in $\mathrm{g} ; \boldsymbol{V}_{1}$ - the pipetted volume of the sample ( 0.1 to $2.0 \mathrm{~mL}) ; \boldsymbol{V}_{2}-$ supplemented volume of the extract by methanol (according to the stated method always $2.0 \mathrm{~mL}$ ); $\boldsymbol{A t}_{0}$ - the initial sample absorbance value.

Total phenolic contents were determined using the FolinCiocaltu method, using Gallic acid as standard (SánchezRangel et al., 2013). From the prepared sample extracts, 0.1 to $1.0 \mathrm{ml}$ was pipetted and made up to $1.0 \mathrm{~mL}$ with deionized water. After standing for $5 \mathrm{~min}, 5.0 \mathrm{~mL}$ of Folin-Ciocalteu reagent, and $4.0 \mathrm{~mL}$ of $7.5 \%$ sodium carbonate solution were added. After 1 hour, the absorbance of the examined solutions is measured at $765 \mathrm{~nm}$.

The determination of L-ascorbic acid was performed by the HPLC method, using sample extract in $2 \%$ oxalic acid medium (Hegedús et al., 2019b).

\section{Statistical analysis}

Statistical evaluation of the two averages was performed by paired t-test at the significance level $\alpha=0.05$. The hypothesis was tested:

$\mathrm{H}_{0}: \bar{x}_{\mathrm{A}}=\bar{x}_{\mathrm{B}}$ against the alternative $\mathrm{H}_{1}: \bar{x}_{\mathrm{A}}^{\mathrm{A}} \neq \bar{x}_{\mathrm{B}}$, where $\bar{x}_{\text {is }}$ the average value.

The evaluation of two modifications of the method in the obtained range of ARA values was made using Youden's graphing method in a linear regression model. The two methods compared can be considered identical if the slope of the regression line is equal to one and the offset of the regression line is zero (ideal case). Since in practice these values are always slightly different from ideal values, they were tested against the ideal values. If the results are consistent over the observed range, the dependence of $y$ $(\operatorname{method} B)$ on $\boldsymbol{x}(\operatorname{method} \mathrm{A})$ is linear:

$$
y=\beta_{1} \cdot x+\beta_{2}
$$


with zero offset $\boldsymbol{\beta 2}=0$ and the slope one $\boldsymbol{\beta 1}=1$, ie. the line equation takes the form:

$$
y=x
$$

When evaluating the results, it was tested whether the estimates of $\boldsymbol{\beta}_{\boldsymbol{1}}$ and $\boldsymbol{\beta}_{\boldsymbol{2}}$ calculated by regression analysis were statistically significantly different (or not different) from the required values for the match of the results of both methods $\left(\boldsymbol{\beta}_{1}=1\right.$ and $\left.\boldsymbol{\beta}_{2}=0\right)$. The hypothesis was tested:

$\mathrm{H}_{0}: \boldsymbol{\beta} \boldsymbol{2}=0$ and $\boldsymbol{\beta} \boldsymbol{1}=1$, against the alternative

$\mathrm{H}_{1}: \boldsymbol{\beta} \boldsymbol{2} \neq 0$ and $\boldsymbol{\beta} \boldsymbol{1} \neq 1$.

The estimated offset of the regression line $\boldsymbol{\beta}_{2}$, calculated by the linear regression should be in the area:

$$
b_{2}-t_{1-\alpha / 2}(n-2) . V_{s_{\mathrm{b} 2}} \leq \beta_{2} \leq b_{2}+t_{1-\mathrm{a} / 2}(n-2) . V_{s_{\mathrm{b} 2}}
$$

If the calculated interval includes zero, then $\boldsymbol{\beta}_{\mathbf{2}}$ cannot be considered significantly different from zero.

Similarly for the slope:

$$
b_{1}-t_{1-\alpha / 2}(n-2) . \sqrt{ } s_{\mathrm{b} 1} \leq \beta_{1} \leq b_{1}+t_{1-\mathrm{a} / 2}(n-2) \cdot \sqrt{ } s_{\mathrm{b} 1}
$$

Where: $\boldsymbol{b}_{1}$ - an estimate of the slope of the regression line, $\boldsymbol{b}_{2}-$ an estimate of the offset of the regression line, $\boldsymbol{t}_{1-\mathrm{a} / 2}$ $\left(\boldsymbol{n}\right.$-2) - a quantile (critical value), $\boldsymbol{s}_{\mathrm{b} 2}$ - the standard deviation of the estimate of $\boldsymbol{\beta}_{2}, \boldsymbol{s}_{\mathrm{b} 1}-$ the standard deviation of the estimate of $\boldsymbol{\beta}_{1}$.

If the calculated interval also includes a unit, the $\boldsymbol{\beta}_{\boldsymbol{1}}$ region cannot be considered significantly different from one (Meloun and Militký, 1994; Hegedüs, Čepelová, and Hegedúsová, 2015).
The linear regression and correlation analysis method were used to evaluate the dependence of ARA on the monitored fruit substances. The strength of the correlation relationship was evaluated by the correlation coefficient value. Correlation coefficient values of 0.7 to 0.9 were considered strong, so there is a strong interdependence between variables. Values 0.3 to 0.7 were considered for moderate and values 0.1 to 0.3 for weak correlation (Dancey and Reidy, 2004).

\section{RESULTS AND DISCUSSION}

The method evaluation

One of several methods of antioxidant activity determination is the DPPH method. The results of this method are often referred to as antiradical activity (ARA) since the reaction mechanism involves quenching stable DPPH radicals with the antioxidant of the substance to be tested. The first reactions of antioxidants with DPPH occur in approximately the first 30 seconds, but moderate reactions are usually complete within 2 min (SánchezMoreno, Larrauri, and Saura-Calixto, 1998). Then the decolorization rate of the reaction mixture gradually decreases until the stabilization decrease. Ultimately, the time after which the absorbance value is read is the result of a compromise between the time required and the relative stabilization of the quenching of the free radicals DPPH and is often given for $30 \mathrm{~min}$ (Gülcin, 2005).

The course of the quenching reaction of the DPPH colour free radicals in the reaction mixture of the extracts and the DPPH solution of several fruit species is shown in Figure 1. Some authors read the decrease in absorbance after a shorter period of antioxidant exposure to DPPH (Vollmannová et al., 2013; Lachman et al., 2006; Jakobek et al., 2008).

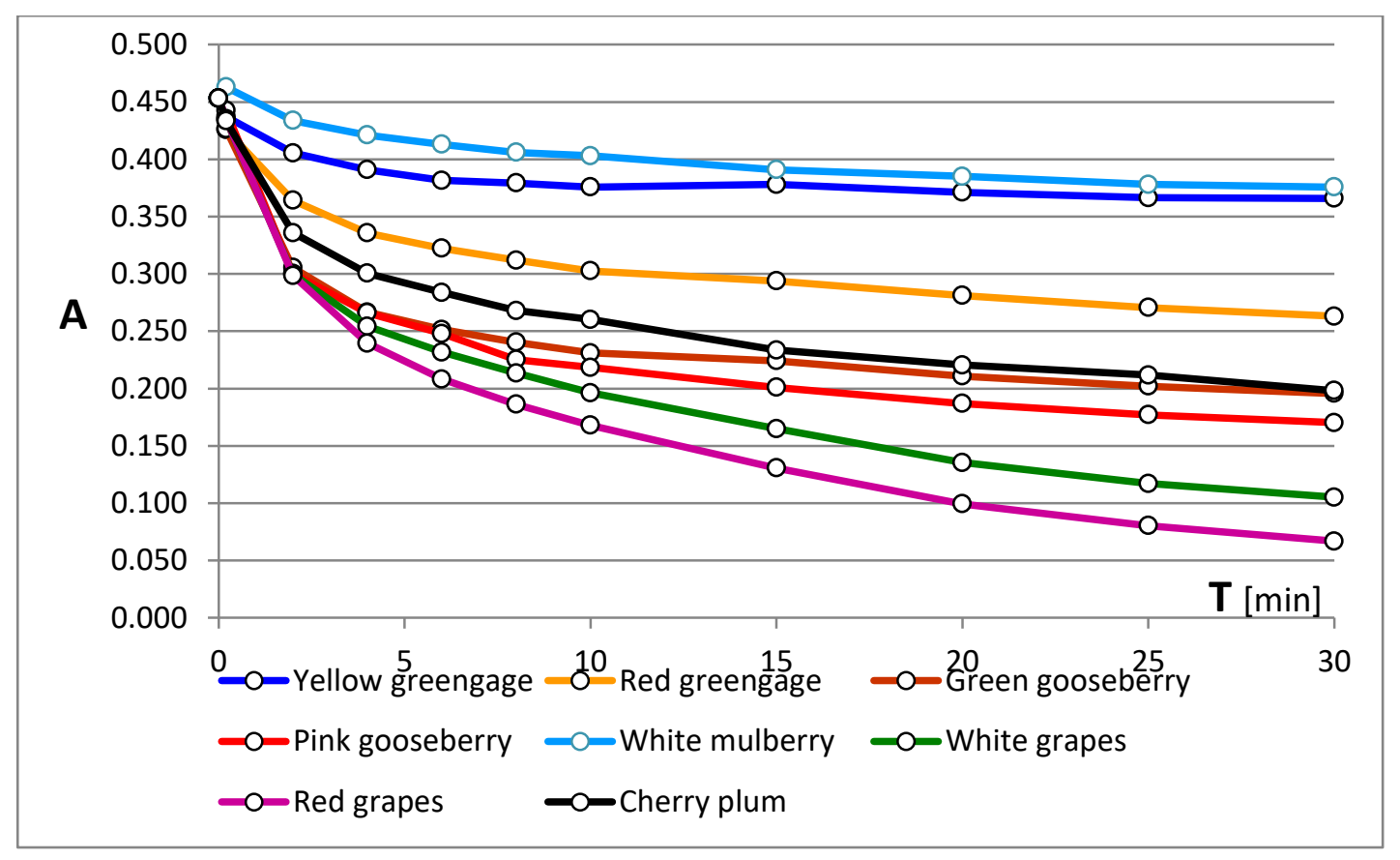

Figure 1 Examples of a decrease in the absorbance of the DPPH reaction mixture with fruit extracts. Note: (A-absorbance; $\mathbf{T}$ - time). 
From the decolouration of the reaction mixture according to the measurement results of Figure 1, it can be seen that in the case of several samples the colour is stabilized slowly. This may have a significant influence on the accuracy of the measurement. In the case of white and red grapes, even after $30 \mathrm{~min}$ the colour did not stabilize, although the changes in the decline are already apparently lower. The DPPH alcohol solution is purple and intensively absorbs output radiation at a wavelength of 517 $\mathrm{nm}$ (the measuring wavelength). When determining the antiradical activity of samples with a high content of anthocyanins, the question arises as to whether this fact will significantly affect the results of the determination, respectively how to adjust the method so that this problem does not occur. This is due to the intensive red to reddishpurple colour of anthocyanins, which give an intense coloration in alcohol extracts (Apak et al., 2007). Several authors report the results of the assay as a measure of the reduction in DPPH staining intensity relative to a blank sample, which is a DPPH solution at the same dilution as the sample reaction mixture with DPPH (Chang et al., 2001; Lachman et al., 2006; Vollmannová et al. 2013). Other authors calculate the results not relative to the blank sample, but on the initial absorbance of each DPPH reaction mixture with the sample separately (Dawidowicz, Wianowska, and Olszowy, 2012), which requires more time and routine measurement, but can eliminate the problem with coloured samples. To determine the possible effect of staining the sample extract on the final result, the different fruits were analysed which gave a red-coloured alcohol extract with different shades of colour using the two methods of measurement. The results of the analyses are shown in Table 1.

After testing the hypothesis at the significance level $\alpha=0.05$ :

$\mathrm{H}_{0}: \bar{x}_{\mathrm{A}}=\bar{x}_{\mathrm{B}}$ against the alternative

$\mathrm{H}_{1}: \bar{x}_{\mathrm{A}} \neq \bar{x}_{\mathrm{B}}$ was found:

that after the analysis of red-coloured fruit extracts containing red-purple plant colorants (Table 1) we accept the zero hypothesis $\left(t_{\text {cal }} \cdot\left\langle t_{\text {crit }}\right)\right.$, thus there is no statistically significant difference between the mean ARA values obtained by two method modifications. In practice, this means that the analyses can be safely performed by correlating the results of the measured absorbance of the samples with the value of the blank, which in laboratory practice is a simpler variant. After examining the agreement of the averages, the evaluation by the Yoden graph method was also proceeded. The Yoden method statistically evaluates the equivalence of the results obtained by both adjustments over the full range of ARA values obtained. The result of the graphical analysis is shown in Figure 2.

Table 1 Antiradical activity value of samples containing red colorants measured by two method modifications.

\begin{tabular}{|c|c|c|}
\hline \multirow{2}{*}{ Fruits } & \multicolumn{2}{|c|}{ ARA $[\% / g]$} \\
\hline & $A_{0 \mathrm{sl}}$ & $A_{0}$ \\
\hline Sour cherry 1 & 810 & 795 \\
\hline Sour cherry 2 & 750 & 759 \\
\hline Raspberry 1 & 547 & 590 \\
\hline Raspberry 2 & 440 & 425 \\
\hline Black currant & 1130 & 1190 \\
\hline Red currant & 544 & 553 \\
\hline Black mulberry 1 & 638 & 817 \\
\hline Black mulberry 2 & 785 & 817 \\
\hline Josta 1 & 646 & 593 \\
\hline Josta 2 & 559 & 677 \\
\hline Red greengage 1 & 114 & 76 \\
\hline Red greengage 2 & 102 & 88 \\
\hline Blueberry 1 & 509 & 465 \\
\hline Blueberry 2 & 463 & 423 \\
\hline Cherry plum 1 & 126 & 119 \\
\hline Cherry plum 2 & 116 & 103 \\
\hline Average & 517 & 530 \\
\hline$S D$ & 283 & 309 \\
\hline \multicolumn{3}{|c|}{$t$-statistic } \\
\hline$t_{\mathrm{cal}}$. & 0.828 & \\
\hline$t_{\text {crit }}$. & 2.131 & \\
\hline Degrees of freedom & 27 & \\
\hline
\end{tabular}

Note: $\boldsymbol{A}_{0}-$ ARA calculated on the initial absorbance of each DPPH reaction mixture with the sample; $\boldsymbol{A}_{0 \mathrm{sl}}-\mathrm{ARA}$ calculated on the blank absorbance value; $\boldsymbol{S D}$ - standard deviation; $t$-statistic: $\boldsymbol{t}_{\text {cal }}-$ calculated value; $\boldsymbol{t}_{\text {crit. }}-$ critical value. 
The graphical presentation of the results of the analyses with both modifications of the method shows that the results obtained by both modifications of the method give a regression line that is almost identical to the ideal course of the regression line. Thus, the graphic assessment does not point to the possibility of a proportional error.

The demonstration of the existence of a proportional error was based on estimates of the parameters $\boldsymbol{\beta} \mathbf{1}$ and $\boldsymbol{\beta} 2$. Linear regression dependence parameter estimates are:

Estimation of the slope of the regression line, $\boldsymbol{b}_{l}$ is 1.015 , Regression line offset estimate, $\boldsymbol{b}_{2}$ is -8.166 ,

Coefficient of determination, $\boldsymbol{R}^{2}$ is 0.962 ,

The number of parallel analyses, $\boldsymbol{n}_{A}$ and $\boldsymbol{n}_{B}$, was 44 .

By solving relations (4) and (5) we found out when the estimate of the guideline $\boldsymbol{b}_{\boldsymbol{1}}$ can be considered equal to 1 and the estimate of the displacement $\boldsymbol{b}_{2}$ equal to 0 . Since in practice we always work with a certain variance of the tested parameters, in our case the confident areas are important, in which the values of $\boldsymbol{\beta}_{\boldsymbol{1}}$ and $\boldsymbol{\beta}_{\boldsymbol{2}}$ lie with the chosen significance level $\alpha=0.05$. The limits of the regression line parameters $\boldsymbol{\beta}_{1}$ and $\boldsymbol{\beta}_{\boldsymbol{2}}$ are:

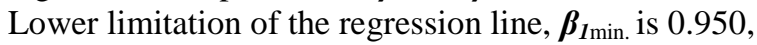

Upper limitation of the slope of the regression line, $\boldsymbol{\beta}_{\boldsymbol{I m a x} \text {. }}$ is 1.079 ,

Lower limitation of the regression line offset, $\boldsymbol{\beta}_{2 \min }$ is -34.813 ,

Upper $\mathrm{r}$ limitation of the regression line offset, $\boldsymbol{\beta}_{2 \max }$ is 18.481 .

The results obtained show that the calculated interval for the offset $\boldsymbol{\beta}_{2}$ also includes zero, so the segment $\boldsymbol{b}_{2}$ cannot be considered significantly different from zero. Similarly, the calculated interval for $\boldsymbol{\beta}_{1}$ includes one, so the estimate of slope $\boldsymbol{b}_{\boldsymbol{1}}$ cannot be considered significantly different from one. For our case, this means that there is no statistically significant difference between the compared method modifications under the conditions described and the concentration range of the assay. In practice, this means that coloured fruit extracts do not affect the result of the analysis simply because of their colour. This can be explained by the fact that the anthocyanin colours that are reddish carriers are also important antioxidants. They can quench free DPPH radicals and thus stain themselves.

\section{Effect of fruit components on ARA}

It was assumed that the value of antiradical activity will be influenced by several fruit substances. Therefore, it was considered a complicated mechanism when monitoring. Since various phenolic compounds as well as ascorbic acid are present in fruits, the ultimate effect was likely the result of their interactions.

\section{Effect of ascorbic acid on ARA}

Ascorbic acid is present in various fruit species and its content is at different concentrations. It is capable of quenching free DPPH radicals. It is sometimes used as an equivalent to express the antiradical activity of a sample (Du Toit, Volsteedt and Apostolides, 2001). The influence of ascorbic acid on the determined ARA value was investigated on the example of analysed fruits. The results of the analyses are shown in Figure 3 as the dependence of ARA on the determined amount of ascorbic acid in all samples analysed, ie. samples containing and without red plant colorants.

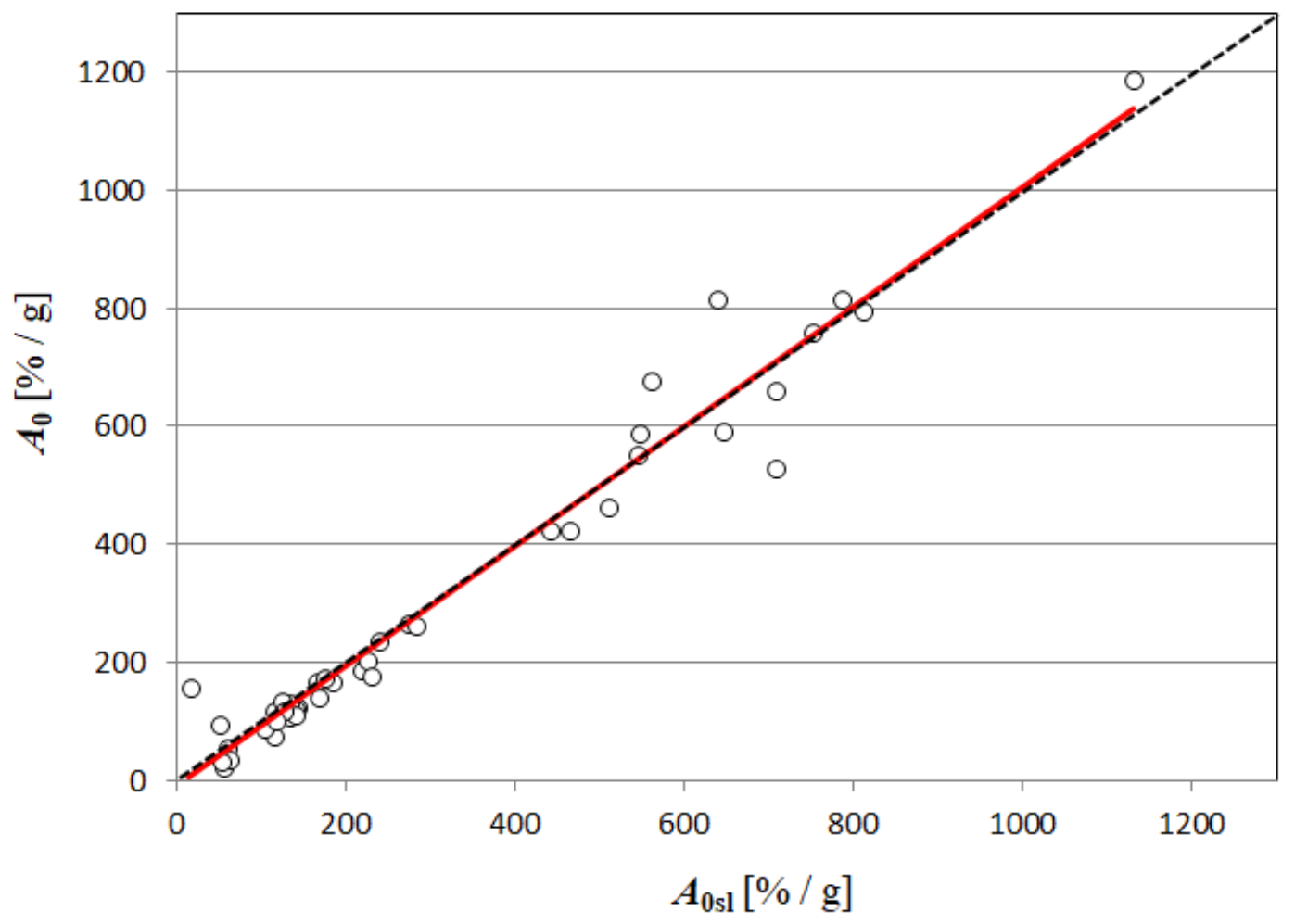

Figure 2 Graphical evaluation of the determined ARA values.

Noter. ARA values calculated on the blank absorbance value $\left(\mathrm{A}_{0 \mathrm{~s} 1}\right)$ and the compared ARA values calculated on the initial absorbance of each DPPH reaction mixture with the sample $\left(\mathrm{A}_{0}\right)$. . . . . - ideal regression line with zero offset and unit slope; regression line calculated from the determined ARA values. 


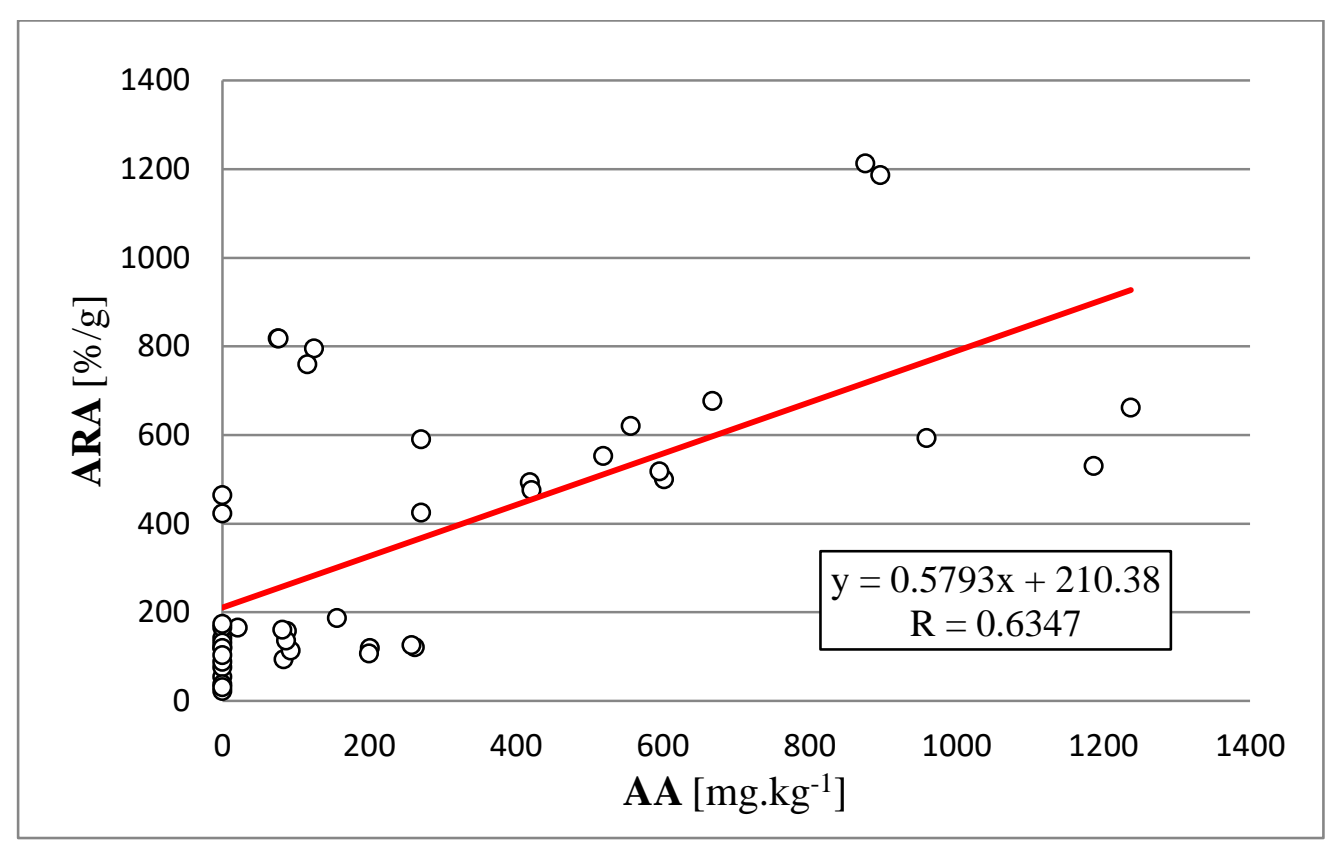

Figure 3 Dependence of the determined antiradical activity (ARA) value on the L-ascorbic acid (AA) content for all samples analysed.

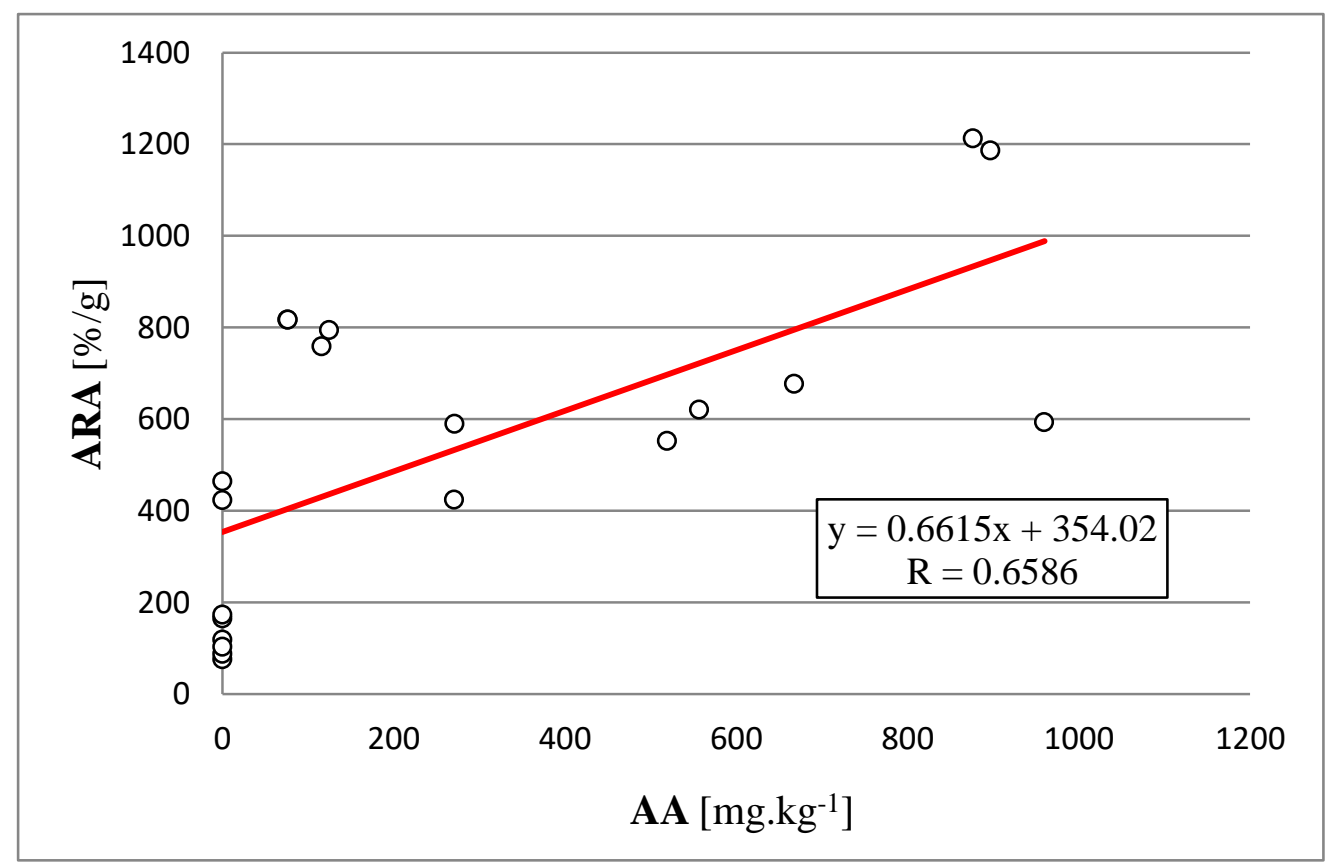

Figure 4 Dependence of the determined antiradical activity (ARA) value on L-ascorbic acid (AA) content for samples containing red plant colorants.

The correlation dependence between monitored values was searched from the analysed data. It was assumed that the higher the content of ascorbic acid, the more it would show its antioxidant properties, thus the higher the ARA value. Data analysis for all analysed samples shows that the calculated correlation coefficient is 0.6347 , indicating a slight correlation between the ascorbic acid content and the corresponding ARA value.

Based on the fact that in addition to ascorbic acid, many other substances, among them red anthocyanin colorants affect the ARA value, the analysed samples were divided into two groups for further investigation of this dependence. In one group, samples with a red-coloured extract from the presence of anthocyanin colorants were included. In the second group were sampled with extract without red plant colorants. Figure 4 shows the dependence of the value determined by ARA on the content of L-ascorbic acid (AA) for red-coloured sample extracts.

The analysis data shows that the calculated correlation coefficient is 0.6586 . As in the case of all samples, it shows a slight correlation between the ascorbic acid content and the corresponding ARA value.

The correlation dependence of ARA on the content of ascorbic acid for samples with extract without red colorants is shown in Figure 5. 
Analysis of the data for samples with no colorant extract shows that the calculated correlation coefficient is 0.9038 . This indicates a strong correlation between the ascorbic acid content and the corresponding ARA value. Based on the correlation dependencies observed, ascorbic acid is the predominant antioxidant component for samples containing no anthocyanin colorants. When investigating the antiradical activity of small kinds of fruits Jakobek and Seruga (2012) also found the significant antiradical potential of ascorbic acid, which was weaker than the potential of some polyphenols. Hegedüs et al. (2010) also found a correlation between antiradical activity and ascorbic acid in apricot, but the correlation relationship was weaker than for polyphenols.

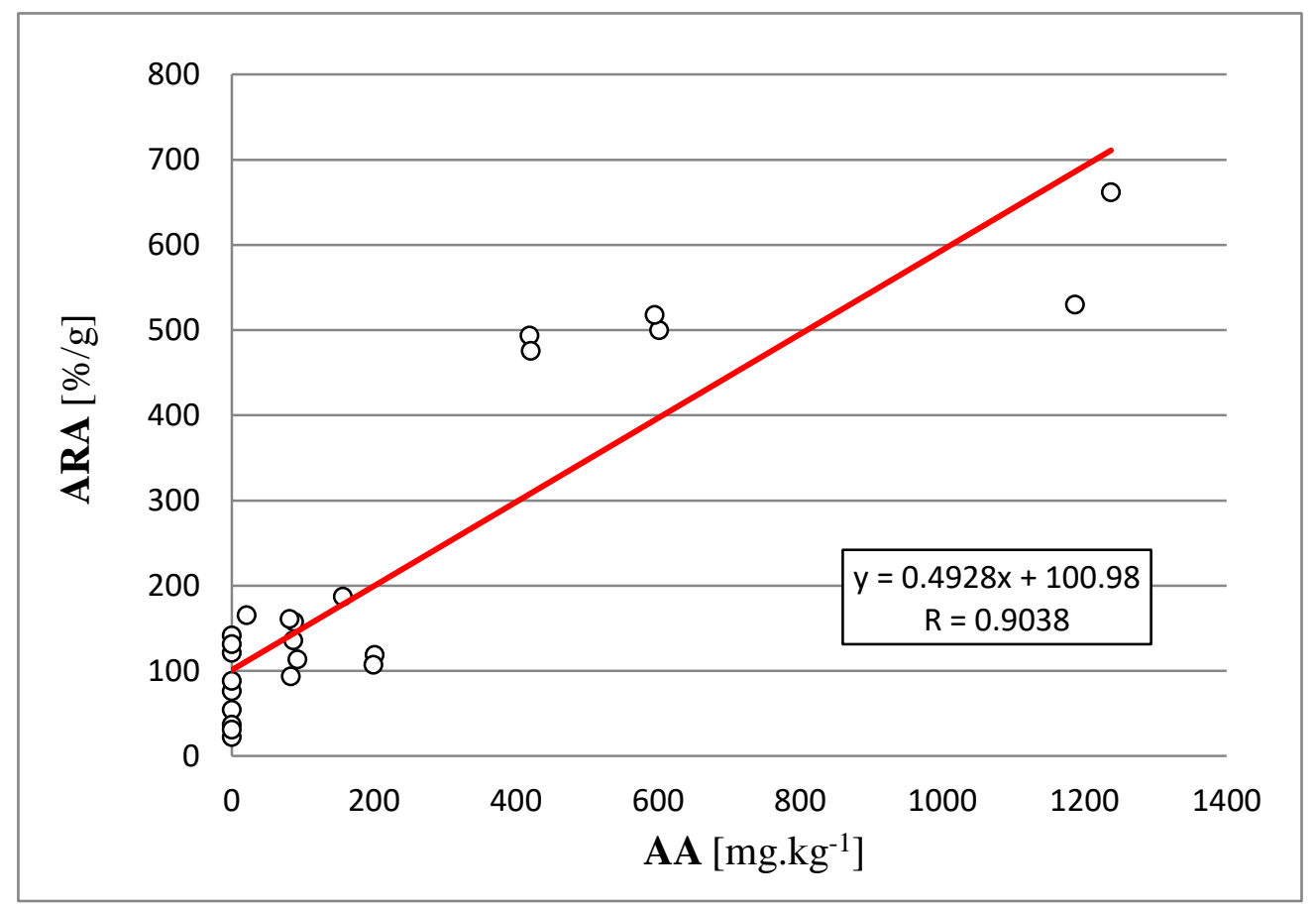

Figure 5 Dependence of the determined antiradical activity (ARA) value on the L-ascorbic acid (AA) content for extracts without red plant colorants.

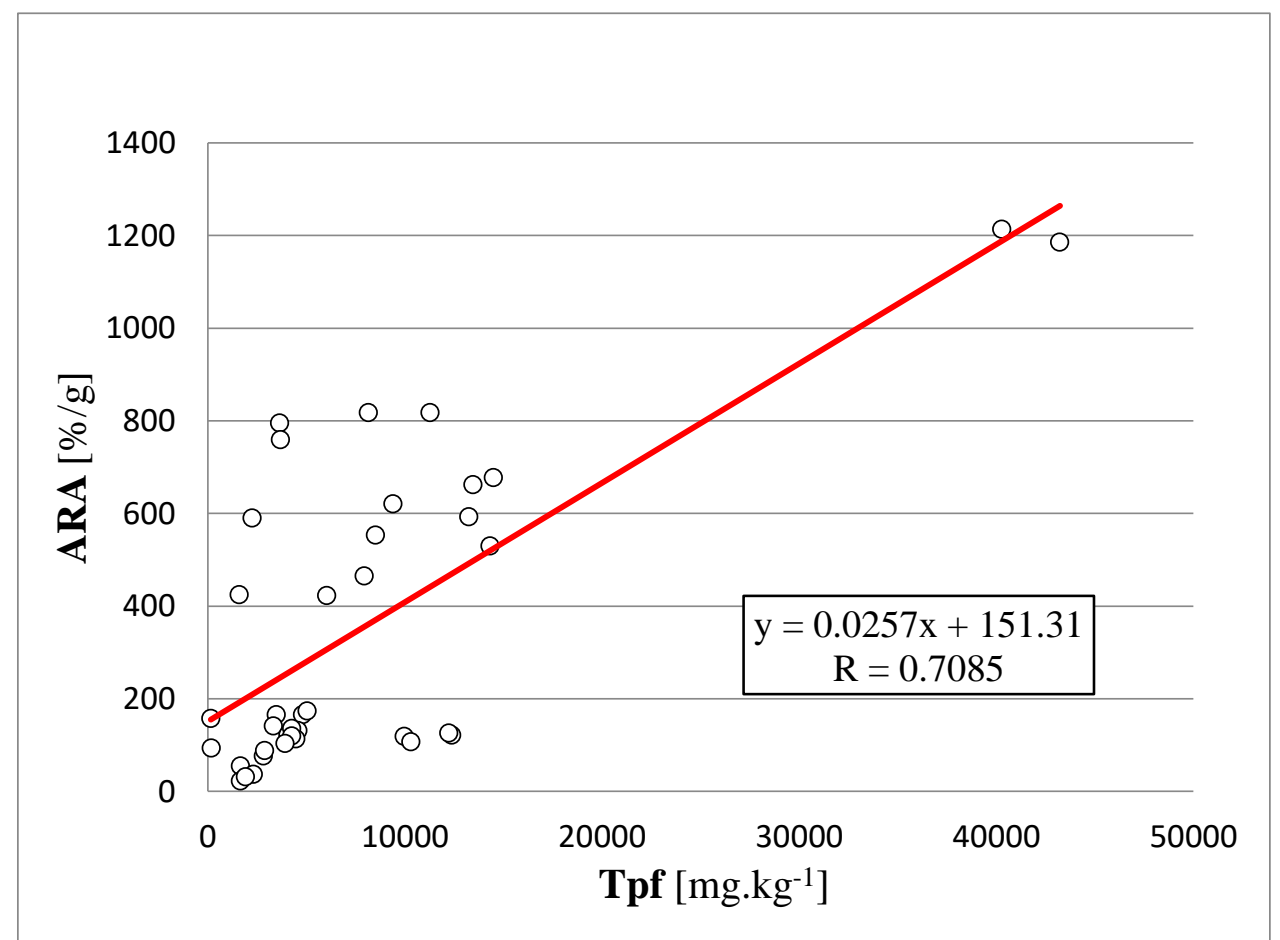

Figure 6 Dependence of the determined antiradical activity (ARA) on the total phenol content (Tph) for all samples analysed. 


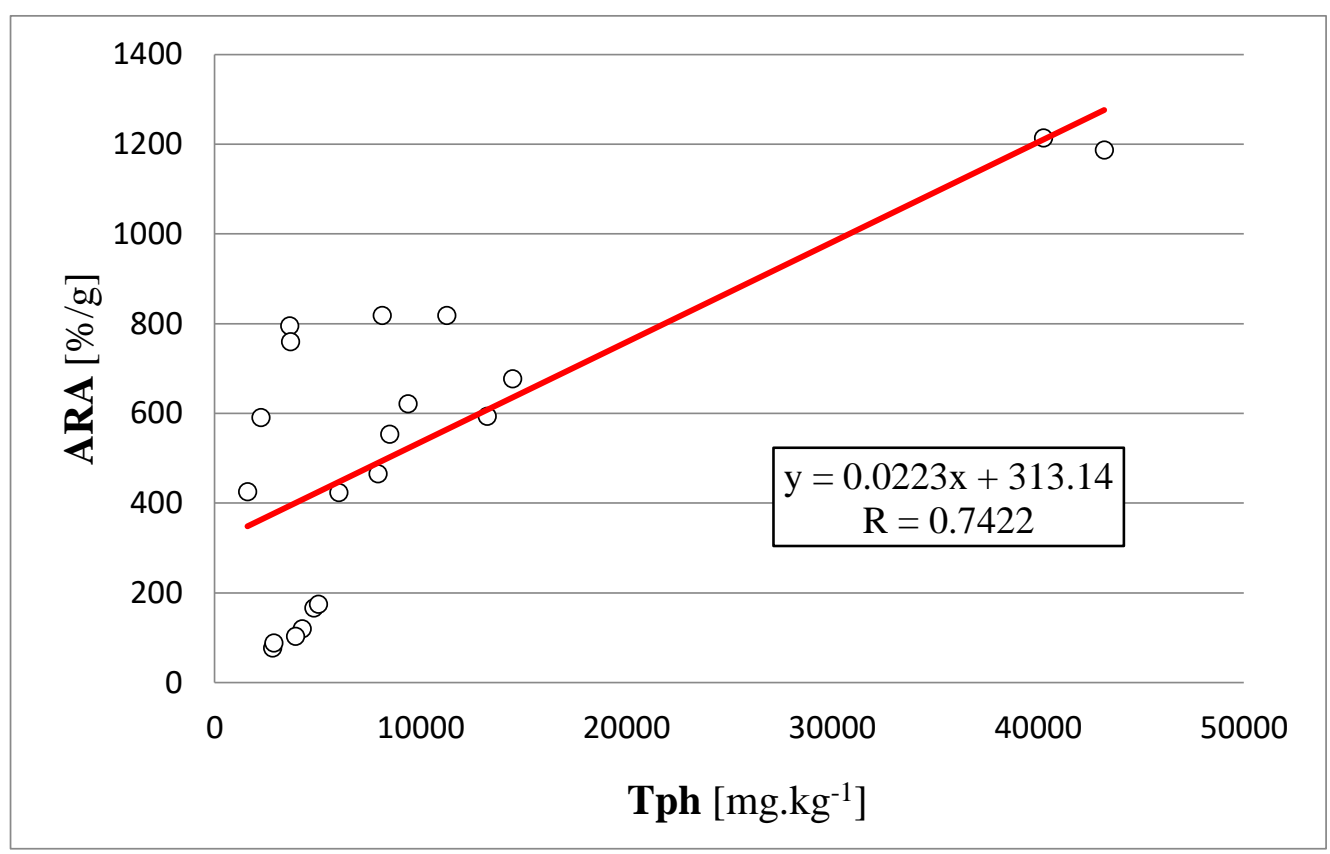

Figure 7 Dependence of determined antiradical activity (ARA) value on the total phenol content (Tph) for samples stained red.

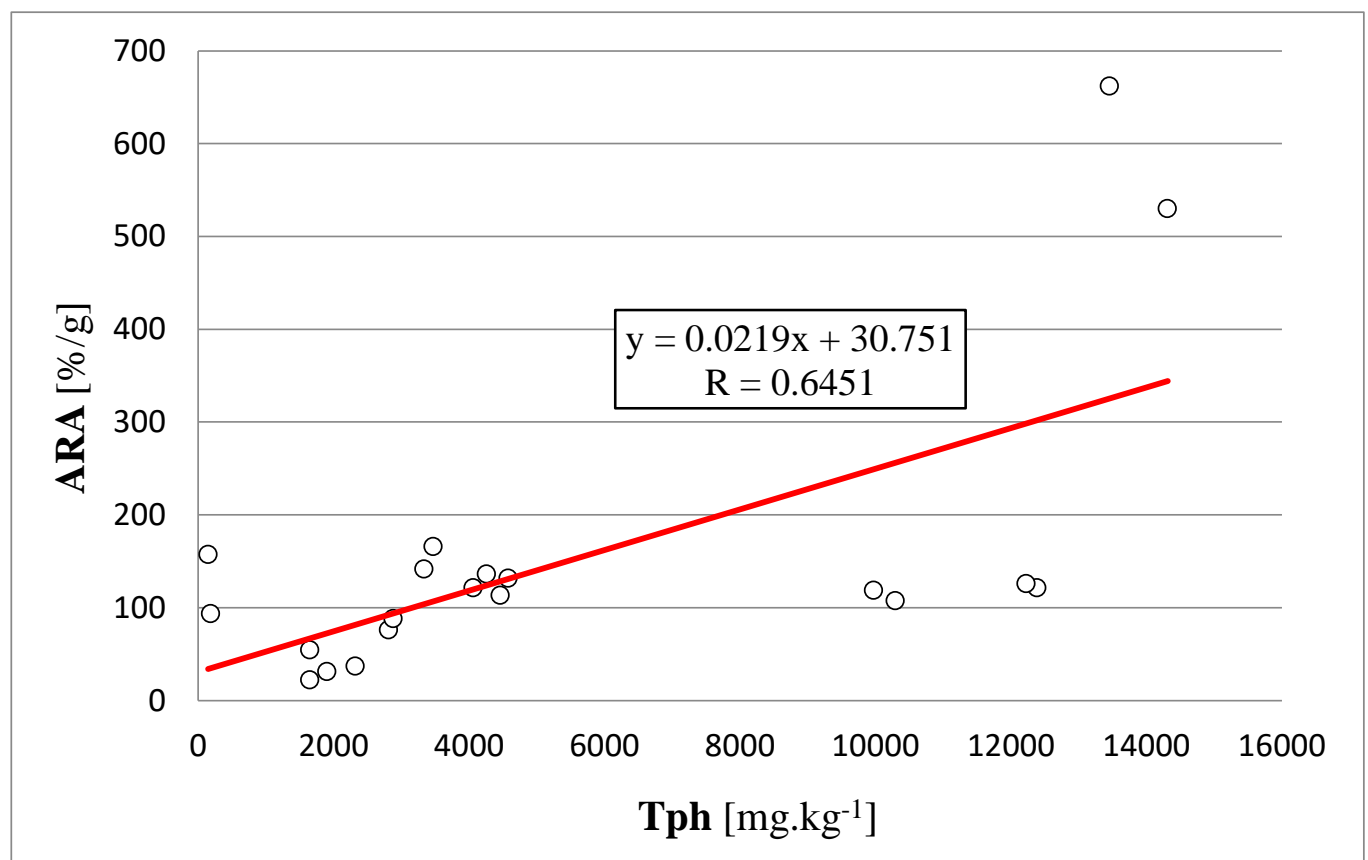

Figure 8 Dependence of determined antiradical activity (ARA) value on the total phenol content (Tph) for samples without the presence of red colorants.

\section{Effect of total phenols on ARA}

Another group of substances with antioxidant properties, we have studied due to their proven effect of ARA are phenolic compounds. These compounds are present in fruits as a large group of flavonoids, including a large number of flavonols, flavones, catechins, flavanones, anthocyanidins, and isoflavonoids. They are characterized by strong antioxidant effects, similarly, like ascorbic acid, they quench free DPPH radicals. The effect of total phenols on ARA based on our analysis is shown in Figure 6.
Based on the correlation analysis, the results show a strong correlation between the polyphenol content and the corresponding ARA value (correlation coefficient value is 0.7085 ). Given the wide variety of phenolic compounds, it is understandable that this results in a milder correlation dependency than that of ascorbic acid.

To obtain more detailed information on the effect of phenolic compounds that carry red colouring of the fruit (anthocyanin colorant group), samples containing these compounds were removed from the study and subjected to further analysis. The results are shown in Figure 7. 
Based on the regression analysis of the results shown in Figure 7 , it is evident that in the case of red-coloured fruits, the strength of the dependence of the ARA on the total phenol content does not differ significantly from that observed for all samples analysed together.

It was expected a significant difference in dependence by comparing the group of red-coloured fruits to the group of red colorants free fruits. Dependence results for fruit species without red plant colorants are shown in Figure 8.

Comparing the results of the correlation analysis for fruit species with and without red colorants, it is clear that the correlation coefficient value for red fruits is higher than for the group of fruits without red colorants (0.7422 vs. 0.6451). The anthocyanin colorants present have a greater influence on the ARA value and indicate a strong correlation dependence.

Similar results were obtained by Jakobek and Seruga (2012) when monitoring the effect of total phenols on ARA in small kinds of fruits. They found a strong correlation between the total phenol content and ARA, while the greatest effect on ARA values was found for anthocyanins.

A significant effect of phenols on the antioxidant activity is also described by Gramza-Michałowska and CzlapkaMatyasik (2011). They observed the highest levels of antioxidant activity in the aronia, which contained the most polyphenols and anthocyanins when considering the different fruit species. A high correlation between polyphenols and ARA has also been shown by other authors (Jakobek et al., 2007; Hegedús et al., 2010; Rinaldi et al., 2013).

\section{CONCLUSION}

Statistical evaluation of the results of the analyses by Youden's graph method revealed that the analysed extracts of red fruit species, although absorbing the light used at $517 \mathrm{~nm}$ as a DPPH free radical solution, did not affect the final ARA value determined. This means that coloured fruit extracts do not affect the result of the analysis by this method due to their colour. Investigation of the effect of the evaluated fruit compounds revealed a strong correlation between the content of ascorbic acid and ARA in samples containing no red plant colorants. For samples containing red colorants, the correlation was slight. The opposite trend was found in the case of fruit species with the presence of red colorants. It was proven a strong dependence of ARA on the total phenol content.

\section{REFERENCES}

Apak, R., Güçlü, K., Demirata, B., Özyürek, M., Çelik, S., Bektaşoğlu, B., Berker, K. I., Özyurt, D. 2007. Comparative evaluation of various total antioxidant capacity assays applied to phenolic compounds with the CUPRAC assay. Molecules, vol. 12, no. 7, p. 1497-1547. https://doi.org/10.3390/12071496

Blois, M. S. 1958. Antioxidant determinations by the use of a stable free radical. Nature, vol. 181, no. 4617, p. 1199-1200. https://doi.org/10.1038/1811199a0

Brand-Willams, W., Cuvelier, M. E., Berset, C. W. 1995. Use of a free radical method to evaluate antioxidant activity. LWT-Food Science and Technology, vol. 28, no. 1, p. 25-30. https://doi.org/10.1016/S0023-6438(95)80008-5
Carmona-Jiménez, Y., García-Moreno, V. M., Igartuburu, J. M., Barosso, C. G. 2014. Simplification of the DPPH assay for estimating the antioxidant activity of wine and wine byproducts. Food Chemistry, vol. 165, p. 198-204. https://doi.org/10.1016/j.foodchem.2014.05.106

Chang, S. T., Wu, J. H., Wang, S. Y., Kang, P. L., Yang, N. S., Shyur, L. F. 2001. Antioxidant activity of extracts from Acacia confusa bark and heartwood. Journal of Agricultural and Food Chemistry, vol. 49, no. 7, p. 3420-3424. https://doi.org/10.1021/jf0100907

Chen, Z., Bertin, R., Froldi, G. 2013. EC50 estimation of antioxidant activity in DPPH assay using several statistical programs. Food Chemistry, vol. 138, no. 1, p. 414-420. https://doi.org/10.1016/j.foodchem.2012.11.001

Dancey, Ch. P., Reidy, J. 2004. Statistics without maths for psychology. The 4thed. Essex, England: Prentice Hall. 636 p. ISBN-13: 9780131249417.

Dawidowicz, A. L., Wianowska, D., Olszowy, M. 2012. On practical problems in estimation of antioxidant activity of compounds by DPPH method (Problems in estimation of antioxidant activity). Food Chemistry, vol. 131, no. 3, p. 1037-1043. https://doi.org/10.1016/j.foodchem.2011.09.067

Du Toit, R., Volsteedt, Y., Apostolides, Z. 2001. Comparison of the antioxidant content of fruits, vegetables and teas measured as vitamin C equivalents. Toxicology, vol. 166 , no. 1-2, p. 63-69. https://doi.org/10.1016/S0300$\underline{483 X(01) 00446-2}$

Gramza-Michałowska, A., Człapka-Matyasik, M. 2011. Evaluation of the antiradical potential of fruit and vegetable snacks. ACTA Scientiarum Polonorum Technologia Alimentaria, vol. 10, no. $1, \quad$ p. 63-72. https://doi.org/10.2478/pjfns-2013-0026

Gülcin, I. 2005. The antioxidant and radical scavenging activities of black pepper (Piper nigrum) seeds. International Journal of Food Sciences and Nutrition. vol. 56, no. 7, p. 491499. https://doi.org/10.1080/09637480500450248

Hegedűs, A., Engel, R., Abrankó, L., Balogh, E.K., Blázovics, A., Hermán, R., Stefanovits-Bányai, É. 2010. Antioxidant and antiradical capacities in apricot (Prunus armeniaca L.) fruits: variations from genotypes, years, and analytical methods. Journal of Food Science, vol. 75, no. 9, p. 722-730. https://doi.org/10.1111/j.1750-3841.2010.01826.x

Hegedűs, O., Čepelová, D., Hegedűsová, A. 2015. The Evaluation of Titrimetric Method for Determination of Fats in Foodstuffs. Chemické listy. vol. 109, no. 9, p. 710-713. Available at: http://www.chemickelisty.cz/ojs3/index.php/chemicke-listy/article/view/316/316.

Hegedűs, O., Hegedűsová, A., Šlosár, M., Mat’ová, A., Szarka, K. 2019a. Antioxidant activity determination of horticultural crops. In: SGEM 2019. Nano, bio and green technologies for a sustainable future. Micro and nano technologies, advances in biotechnology: 19th international multidisciplinary scientific geoconference SGEM. Albena, Bulgaria: 19th international multidisciplinary scientific geoconference SGEM 2019, 30 June - 6 July, 2019, Albena, Bulgaria. p. 543-550. ISBN 978-619-7408-88-1. Available at: https://www.sgem.org/index.php/elibrary?view=publication \& task=show\&id=6420.

Hegedűs, O., Szarka, K., Hegedűsová, A., Gódány, Z., Šlosár, M., Nechifor, A. C., Tonk, S. 2019b. Validation and Quality Assurance of Ascorbic Acid Determination in Agricultural Products. Revista de Chimie, vol. 70, no. 7, p. 2308-2314. Available at: https://www.revistadechimie.ro/pdf/2\%20HEGHEDUS\%207 $\% 2019 . p d f$ 
Hegedűsová, A., Mezeyová, I., Timoracká, M., Šlosár, M., Musilová, J., Juríková, T. 2015. Total polyphenol content and antioxidant capacity changes in dependence on chosen garden pea varieties, Potravinarstvo Slovak Journal of Food Sciences, vol. 9, no. 1, p. 1-8. https://doi.org/10.5219/412

Ivanišová, E., Fikselová, M., Vietoris, V., Mellen, M. 2010. Antioxidant effects of herbal extracts and their food application. Potravinarstvo Slovak Journal of Food Sciences, vol. 4, no. 4, p. 34-37. https://doi.org/10.5219/75

Jakobek, L., Šeruga, M., Novak, I., Medvidović-Kosanović, M. 2007. Flavonols, phenolic acids and antioxidant activity of some red fruits. Deutsche Lebensmittel-Rundschau, vol. 103, no. $8, \quad$ p. $369 . \quad$ Available at: https://bib.irb.hr/datoteka/321086.Jakobek.L._DLR_1038200 7_369-378.pdf.

Jakobek, L., Seruga, M. 2012. Influence of anthocyanins, flavonols and phenolic acids on the antiradical activity of berries and small fruits. International journal of food properties, vol. 15, no. 1, p. 122-133.

https://doi.org/10.1080/10942911003754684

Jakobek, L., Seruga, M., Novak, I., Medvidović-Kosanović, M., Šeruga, B. 2008. Kinetika inhibicije DPPH radikala i antiradikalna aktivnost polifenola iz plodova aronije i bazge (DPPH radical inhibition kinetic and antiradical activity of polyphenolsfrom chokeberry and elderberry fruits). Pomologia Croatica: Glasilo Hrvatskog agronomskog društva, vol. 14, no. 2, p. 101-118. Available at: https://www.academia.edu/1009157/Kinetika_inhibicije_DPP H_radikala_i_antiradikalna_aktivnost_polifenola_iz_plodova _aronije_i_bazge.

Kedare, S. B., Singh, R. P. 2011. Genesis and development of DPPH method of antioxidant assay. Journal of food science and technology, vol. 48, no. 4, p. 412-422. https://doi.org/10.1007/s13197-011-0251-1

Lachman, J., Hamouz, K., Cepl, J., Pivec, V., Sulc, M., Dvorák, P. 2006. Vliv vybranych faktoru na obsah polyfenolu a anti-oxidacni aktivitu hliz brambor (The Effect of Selected Factors on Polyphenol Content and Antioxidant Activity in Potato Tubers). Chemické listy, vol. 100, no. 7, p. 522-527.

Meloun, M., Militký, J. 1994. Statistické zpracování experimentálnich dat (Statistical processing of experimental data). Plus Praha, 840 p. ISBN 80-85297-56-6.

Mishra, K., Ojha, H., Chaudhury, N. K. 2012. Estimation of antiradical properties of antioxidants using DPPH assay: A critical review and results. Food chemistry, vol. 130, no. 4, p. 1036-1043. https://doi.org/10.1016/j.foodchem.2011.07.127

Sánchez-Moreno, C., Larrauri, J. A., Saura-Calixto, F. 1998. A procedure to measure the antiradical efficiency of polyphenols. Journal of the Science of Food and Agriculture, vol. 76, no. 2, p. 270-276. https://doi.org/10.1002/(SICI)10970010(199802)76:2<270::AID-JSFA945>3.0.CO;2-9

Rinaldi, M., Caligiani, A., Borgese, R., Palla, G., Barbanti, D., \& Massini, R. 2013. The effect of fruit processing and enzymatic treatments on pomegranate juice composition, antioxidant activity and polyphenols content. LWT-Food Science and Technology, vol. 53, no. 1, p. 355-359. https://doi.org/10.1016/j.lwt.2013.02.015

Sánchez-Rangel, J. C., Benavides, J., Heredia, J. B., Cisneros-Zevallos, L., Jacobo-Velázquez, D. A. 2013. The Folin-Ciocalteu assay revisited: improvement of its specificity for total phenolic content determination. Analytical Methods, vol. 5, no. 21, p. 5990-5999. https://doi.org/10.1039/C3AY41125G
Vollmannová, A., Margitanová, E., Tóth, T., Timoracká, M., Urminská, D., Bojňanská, T., Čičová, I. 2013. Cultivar influence on total polyphenol and rutin contents and total antioxidant capacity in buckwheat, amaranth, and quinoa seeds. Czech Journal of Food Sciences, vol. 31, no. 6, p. 589595. https://doi.org/10.17221/452/2012-CJFS

Žiarovská, J., Shevtsova, T., Gažo, J., Brindza, J., Garkava, K., Bežo, M. 2014. Antioxidačná aktivita pel'u briez vo vzt’ahu k expresii BetV1 alergénu (Antioxidant Activity of Birch Pollen in Relation to Expression of BetV1 Allergen). Chemické listy, vol. 108, no. 11, p. 1080-1083. Available at: http://www.chemicke-listy.cz/ojs3/index.php/chemickelisty/article/view/441/441.

\section{Contact address:}

*doc. Ing. Ondrej Hegedüs, PhD., J. Selye University, Faculty of Economics and Informatics, Department of Management, Hradná 21, 94501 Komárno, Slovakia, Tel.: +421 353260865 ,

E-mail: hegeduso@ujs.sk

ORCID: https://orcid.org/0000-0002-0643-7014

Bc. Boglárka Borovicza, J. Selye University, Faculty of Education, Department of Chemistry, Bratislavská cesta 3322, 94501 Komárno, Slovakia, Tel.: +421 353260 865, E-mail: $121641 @$ student.ujs.sk ORCID: https://orcid.org/0000-0003-4266-7869

Mgr. Katarína Szarka, PhD., J. Selye University, Faculty of Education, Department of Chemistry, Bratislavská cesta 3322, 94501 Komárno, Slovakia, Tel.: +421 353260 683, E-mail: szarkak@ujs.sk

ORCID: https://orcid.org/0000-0002-0741-3364

Andrea Vargová, J. Selye University, Faculty of Education, Department of Chemistry, Bratislavská cesta 3322, 94501 Komárno, Slovakia, Tel.: +421 353260 873, E-mail: vargovaa@ujs.sk

ORCID: https://orcid.org/0000-0001-7011-0414

Bc. Dániel Reménység, J. Selye University, Faculty of Education, Department of Chemistry, Bratislavská cesta 3322, 94501 Komárno, Slovakia, Tel.: +421 353260 683, E-mail: 121634@student.ujs.sk

ORCID: https://orcid.org/0000-0002-2745-9351

Mgr. Adriána Mat'ová, Slovak University of Agriculture in Nitra, Faculty of Horticulture and Landscape Engineering, Department of Vegetable Production, Tr. A. Hlinku 2, 94976 Nitra, Slovakia, Tel.: +421 37641 4262, E-mail: xlidikova@is.uniag.sk

ORCID: https://orcid.org/0000-0003-3325-0834

Bc. Barnabás Czibor, J. Selye University, Faculty of Education, Department of Chemistry, Bratislavská cesta 3322, 94501 Komárno, Slovakia, Tel.: +421 353260 873, E-mail: 122044@student.ujs.sk

ORCID: https://orcid.org/0000-0003-3700-610X

prof. RNDr. Alžbeta Hegedüsová, PhD., Slovak University of Agriculture in Nitra, Faculty of Horticulture and Landscape Engineering, Department of Vegetable Production, Tr. A. Hlinku 2, 94976 Nitra, Slovakia, Tel.: +421 37641 4712,

E-mail: alzbeta.hegedusova@uniag.sk

ORCID: https://orcid.org/0000-0001-6994-1077

Corresponding author: * 